\title{
PENERAPAN PENDEKATAN OPEN-ENDED UNTUK MENINGKATKAN PENALARAN MATEMATIK SISWA SMP
}

\author{
Indri Herdiman \\ STKIP Siliwangi Bandung, Cimahi, \\ herdiman0111@stkipsiliwangi.ac.id
}

\begin{abstract}
This study aims or determining whether the achievement and improvement of mathematical reasoning of junior high school students who learn using open-ended approach is better than using conventional learning. The research conducted was experimental research. The population in this study was all junior high school students in Kabupaten Bandung Barat. While the samples were taken two classes VIII from one grade, where class VIII B became experimental class and class VIII A became the control class. The instrument used in the research was in the form of five essay tests that measure students' mathematical reasoning. To know the improvement of student's mathematical reasoning before and after learning activity, normalized gain calculation was done, then data of pretest and postes result were processed by normality, homogeneity and difference average tests. Based on the analysis of the data resul processing in this study, it could be concluded that the achievement and improvement of mathematical reasoning among students who learn using open-ended approach was better than using conventional learning.
\end{abstract}

Keywords: Open-Ended Approach, Mathematical Reasoning.

\begin{abstract}
Abstrak
Penelitian ini bertujuan untuk mengetahui apakah pencapain dan peningkatan penalaran matematik siswa SMP yang pembelajarannya menggunakan pendekatan open-ended lebih baik daripada yang menggunakan pembelajaran konvensional. Penelitian yang dilaksanakan adalah penelitiankuasi eksperimen.Populasi dalam penelitian ini adalah seluruh siswa SMP di Kabupaten Bandung Barat.Sedangkan sampelnya diambil dua kelas VIII di salah satu sekolah yang berada di Kabupaten tersebut, dimana kelas VIII B menjadi kelas eksperimen dan kelas VIII A menjadi kelas kontrol. Instrumen yang digunakan dalam penelitian adalah berupa lima soal tes berbentuk uraian yang mengukur penalaran matematik siswa. Cara mengetahui seberapa besar peningkatan penalaran matematik siswa sebelum dan sesudah kegiatan pembelajaran, dilakukan perhitungan gain ternormalisasi, kemudian data hasil pretes dan postes diolah dengan langkah uji normalitas, uji homogenitas dan uji perbedaan rata-rata. Berdasarkan analisis hasil pengolahan data pada penelitian ini dapat disimpulkan bahwa pencapain dan peningkatan penalaran matematik antara siswa yang pembelajarannya menggunakan pendekatan open-ended lebih baik daripada yang menggunakan pembelajaran konvensional.
\end{abstract}

Kata kunci: Pendekatan Open-Ended, Penalaran Matematik. 


\section{PENDAHULUAN}

Penalaran matematik siswa merupakan salah satu aspek penting yang ditekankan dalam tujuan pendidikan matematika, karena dapat digunakan untuk menyelesaikan persoalan matematika dan masalahmasalah lain. Sejalan dengan itu Depdiknas (Juariah, 2008), mengungkapkan bahwa materi matematika dan penalaran matematik merupakan dua hal yang tidak dapat dipisahkan, yaitu materi matematika dipahami melalui penalaran dan penalaran dipahami dan dilatihkan melalui belajar materi matematika. Di saat belajar matematika para siswa akan selalu dihadapkan dengan proses penalaran untuk itu kemampuan penalaran siswa yang masih rendah harus ditingkatkan melalui belajar matematika.

Shadiq (2007), berpendapat bahwa seni bernalar sangat dibutuhkan di setiap segi dan setiap sisi kehidupan ini agar setiap warga bangsa dapat menganalisis setiap masalah yang muncul, dapat memecahkan masalah dengan tepat, dapat menilai sesuatu secara kritis serta dapat mengemukakan pendapat maupun idenya secara logis. Sedangkan menurut Krulik dan Rudnick (Haryono, 2008) penalaran merupakan aspek kunci dalam mengembangkan kemampuan berpikir kritis dan kreatif dari siswa.

Mengingat pentingnya penalaran matematik siswa, prestasi yang dihasilkan melalui kemampuankognitif siswa haruslah baik, namun pada kenyataannya dilapangan berdasarkan pemaparan yang disampaikan oleh guru bidang studi matematika disekolah yang akan diteliti bahwa penalaran matematik siswa masih tergolong rendah, pernyataan tersebut didukungdengan nilai dari tes soal penalaran yang pernah diujikan disekolah tersebut . Hal ini sesuai dengan yang dikemukakanMukhlis (Kasmiri, 2005), bahwa kemampuan penalaran siswa Indonesia sangat rendah. Penalaran siswa yang rendah akan berdampak pada hasil belajar siswa maka penalaran siswa harus ditingkatkan.

$$
\text { Menyadari kenyataan di }
$$
lapangan maka pengembangan kemampuan tersebut harus diperhatikan dalam pembelajaran. Kondisi siswa belajar secara pasif, jelas tidak menguntungkan terhadap peningkatan penalaran matematiknya. Untuk itu perlu usaha guru agar siswa belajar secara aktif.

Pendekatan pembelajaran diupayakan dapat mengaktifkan siswa untuk mengembangkan daya nalar matematik siswa sehingga siswa mampu mengembangkan dan mengevaluasi argumentasi.Salah satu pendekatan pembelajaran yang bisa dipilih adalah pendekatan openendeddengan menerapkan media pembelajaran berupa Lembar Kerja Siswa (LKS) yang berbasis openendedproblem.

Pendekatan open-ended adalah pembelajaran yang membangun kegiatan interaktif antara matematika dan siswa sehingga mengundang siswa 
untuk menjawab permasalahan melalui berbagai strategi. Dalam pendekatan open-ended guru memberikan permasalahan kepada siswa yang solusinya tidak hanya satu jalan/ cara. Guru hendaknya memanfaatkan keberagaman cara atau prosedur untuk menyelesaikan masalah, agar memberi pengalaman kepada siswa dalam menemukan sesuatu yang baru berdasarkan pengetahuan, keterampilan, dan cara berpikir matematika yang telah diperoleh sebelumnya.

$$
\text { Penyajian soal dalam }
$$
pendekatan open-ended yang akan dilakukan dalam penelitian ini menggunakan media berupa LKS yang dapat difungsikan untuk menemukan dan mengaplikasikan suatu konsep. Dengan LKS berbasis open-ended problem dimana berisi persoalan terbuka, maka rasa ingin tahu siswa akan semakin tinggi. Penggunaan LKS berbasis open-endedproblem dapat menumbuhkan ide, kreativitas serta sikap kritis siswa. Siswa dapat mengembangkan metode, cara, atau pendekatan yang bervariasi dalam memperoleh jawaban, sehingga lebih mementingkan proses daripada hasil. Hal ini akan membentuk pola pikir keterpaduandan melatih daya nalar siswa.

Penelitian ini bertujuan untuk menganalisis pencapaian dan peningkatan penalaran matematik siswa yang pembelajarannya menggunakan pendekatan openendedlebih baik dari pada siswa yang menggunakan pembelajaran konvensional.

\section{KAJIAN TEORI \\ Penalaran Matematik}

Secara garis besar terdapat dua penalaran, yaitu penalaran induktif dan deduktif. Penalaraninduktif merupakan proses penarikan kesimpulan dari kasus-kasus individual nyata menjadi kesimpulan yang bersifat umum. Sedangkan penalaran deduktif adalah kegiatan atau aktivitas berpikir untuk menarik kesimpulan dari yang bersifat umum menjadi khusus(Yuniarti, 2007)

Deduksi dan induksi memiliki kesamaan dimana keduanya merupakan argumen (Urman, 2010). Argumen adalah serangkaian proposisi yang mempunyai struktur, terdiri dari beberapa pernyataan dan satu konklusi atau kesimpulan.

Sumarmo

mengungkapkan beberapa kemampuan yang dapat digolongkan ke dalam penalaran matematik, diantaranya adalah: (1) Menarik kesimpulan logis, (2) memberi penjelasan terhadap model, fakta, sifat dan hubungan, (3) memperkirakan jawaban dan proses solusi, (4) menggunakan pola dan hubungan untuk menganalisa situasi matematik, (5) membuat dan menyusun konjektur, (6) merumuskan lawan contoh (counter-example), (7) mengikuti aturan inferensi, memeriksa validitas argument, (8) menyusun argumen yang valid, (9) menyusun pembuktian langsung, pembuktian tak langsung dan menggunakan induksi matematika.

$$
\text { Misalnya siswa dapat }
$$
menyelesaikan kasus bangun ruang sisi datar seperti berikut: Misalkan ada 
20 batang kawat yang memiliki panjang sama masing-masing $2 \mathrm{~m} .12$ batang kawat disusun menjadi kerangka bangun berbentuk kubus, sedangkan sisanya akan dibuat kerangka balok. Karena kekurangan jumlah kawat, maka dari 8 kawat yang tersisa setengahnya dipotong menjadi dua bagian sama panjang. Kedua kerangka bangun tersebut akan dilapisi oleh kain. Andaikan kerangka balok harus dilapisi sebanyak 2 lapis, maka simpulkan bangun mana yang memerlukan kain lebih luas! Jelaskan alasan yang mendasari kesimpulan tersebut.

Siswa dianggap bisa menyelesaikan soal tersebut jika siswa dapat menarik kesimpulan logik, yang merupakan salah satu dari indikator penalaran matematik.

\section{Pendekatan Open-Ended}

Soal yang memiliki multi penyelesaian merupakan pengertian dari soal terbuka /open-ended problem (Mahmudi, 2008).Sedangkan menurut Suherman, et. al. (2001) problem yang diformulasikan memiliki multijawaban yang benar disebut problem tak lengkap atau disebut juga problem openended atau problem terbuka.Pada saat proses pembelajaran soalopenended dapat diberikan kepada siswa dengan tujuanuntuk mendapatkan jawaban tetapi lebih menekankan pada cara bagaimana sampai pada suatu jawaban. Tujuan tersebut dapat tercapai ketika siswa mengembangkan metode, cara, atau pendekatan yang berbeda dalam menjawab permasalahan yang diberikan dan bukan berorientasi pada jawaban atau hasil akhir. Sehingga, tidak hanya ada satu pendekatan atau metode dalam memperoleh jawaban, namun beberapa atau banyak

Aspek keterbukaan dalam soal terbuka dapat diklasifikasikan ke dalam tiga tipe, yaitu: (1) terbuka proses penyelesaiannya, yakni soal itu memiliki beragam cara penyelesaian, (2) terbuka hasil akhirnya, yakni soal itu memiliki banyak jawab yang benar, dan (3) terbuka pengembangan lanjutannya, yakni ketika siswa telah menyelesaikan suatu soal, selanjutnya mereka dapat mengembangkan soal baru dengan mengubah syarat atau kondisi pada soal yang telah diselesaikan (Suherman, et. Al; 2001)

Dalam membuat masalah open-ended, Jerry P. Becker \& Shigeru Shimada (Suherman, et. al, 2001) memberikan beberapa hal yang dapat dijadikan acuan dalam mengkreasi masalah tersebut, antara lain:(1) menyajikan permasalahan melalui situasi fisik yang nyata dimana konsep matematika dapat dikaji dan diamati siswa, (2) soal-soal pembuktian dapat diubah sedemikian rupa sehingga siswa dapat menemukan hubungan dan sifat-sifat dari variable dalam masalah itu, (3) menyajikan bangun-bangun geometri sehingga siswa dapat membuat suatu konjektur, (4) memberikan suatu barisan bilangan atau tabel bilangan sehingga siswa dapat menemukan aturan matematika, (5) memberikan contoh konkret dalam beberapa kategori sehingga siswa dapat mengelaborasi sifat-sifat dari 
contoh itu untuk menemukan sifatsifat yang umum.

Tahap pelaksanaan kegiatan pembelajaran yaitu siswa diberi LKS berbasis open-ended problem untuk dikerjakan secara individu kemudian setelah seluruh siswa selesai mengerjakan LKS terjadi diskusi klasik antara guru dan peserta didik dalam membahas hasil kerja siswa.

Keunggulan pendekatan openended menurut Suherman, et. al (2001) antara lain: (1) siswa berpartisipasi lebih aktif dalam pembelajaran dan sering mengekspresikan ide, (2) siswa memiliki kesempatan lebih banyak dalam memanfaatkan pengetahuan dan keterampilan matematik secara komprehensif, (3) siswa dengan kemampuan matematika rendah dapat merespon permasalahan dengan cara mereka sendiri, (4) siswa secara intrinsik termotivasi untuk memberikan bukti atau penjelasan, (5) siswa memiliki pengalaman banyak untuk menemukan sesuatu dalam menjawab permasalahan.

Dari uraian tersebut dapat disimpulkan bahwa pendekatan openended adalah pendekatan dimana guru sebagai fasilitator dan pengarah sedangkan siswa aktif melakukan kegiatan sesuai prosedur atau langkah kerja yang terdapat pada media pembelajaran berupa Lembar Kerja Siswa (LKS) berbasis open-ended problem yaitu suatu bahan ajar yang memuat permasalahan atau persoalan terbuka dimana siswa dapat bebas mengembangkan strategi atau cara untuk menyelesaikan suatu permasalahan. Siswa dapat menyelesaikan suatu permasalahan dengan banyak cara dan mungkin juga banyak jawaban yang benar. Tujuannya agar kemampuan berpikir matematika siswa dapat berkembang secara maksimal dan kegiatankegiatan kreatif dari setiap siswa terkomunikasikan melalui proses belajar-mengajar.

\section{METODE PENELITIAN}

Penelitian ini menggunakan penelitian kuantitatif yang dilaksanakan pada tahun 2014 di salah satu SMP swasta yang berada di Kabupaten Bandung Barat, penelitian yang dilaksanakan adalah penelitiankuasi eksperimen. Sehingga desain penelitiannya adalah sebagai berikut:

$\begin{array}{lll}O \quad X & O \\ \text { O } & \text { O } \\ \text { 2005). } & & \end{array}$

Keterangan:

$\mathrm{O}:$ Pre tes $=$ Post tes (soal penalaran matematik)

$\mathrm{X}$ : Pembelajaran menggunakan pendekatan open-ended

Populasi dalam penelitian ini adalah seluruh siswa SMP yang berada di Kabupaten Bandung Barat.Sedangkan sampelnya diambil dua kelas VIII dari salah satu sekolah yang berada di kabupaten tersebut, dimana kelas VIII B menjadi kelas eksperimen dan kelas VIII A menjadi kelas kontrol. Instrumen dalam penelitian ini adalah lima soal tes berbentuk uraian yang telah 
dikonsultasikan terlebih dahulu dengan dosen ahli dan telah diuji validitas, reliabilitas, daya pembeda dan indeks kesukarannya.

$$
\text { Cara mengetahui seberapa }
$$
besar peningkatan penalaran matematik siswa sebelum dan sesudah kegiatan pembelajaran, dilakukan perhitungan gain ternormalisasi dengan rumus dan klasifikasi hasil indeks gain menurut Hake (Hidayat, 2011: 35) sebagai berikut:

$$
\operatorname{Gain}(g)=\frac{\text { Skor akhir }- \text { skor awal }}{\text { SMI }- \text { skor awal }}
$$

Adapun tingkat perolehan skor gain ternormalisasi dikelompokkan kedalam tiga kategori yaitu:

$$
\begin{array}{ll}
0,70<(\mathrm{g}) & : \text { Tinggi } \\
0,30 \leq(\mathrm{g}) \leq 0,70 & : \text { Sedang } \\
0,30>(\mathrm{g}) & : \text { Rendah }
\end{array}
$$

Data hasil dari penelitian ini diolah dengan menggunakan bantuan program software MINITAB 16 dengan langkah pertama uji normalitas dilakukan dengan menggunakan uji Kolmogorov-Smirnov dengan kriteria jika nilai $P$-Value $>0,05$ maka sampel berdistribusi normal. Jika ternyata keduanya normal dilanjutkan dengan uji homogenitas varians, akan tetapi jika salah satu atau keduanya tidak normal langkah selanjutnya menggunakan statistika non parametrik dalam hal ini menggunakan uji mean whitney. Selanjutnya untuk uji homogenitas varians menggunakan uji-F dengan kriteria jika nilai $P$-Value $>0,05$ maka disimpulkan varians kedua kelas sampel homogen. Untuk uji signifikan perbedaan rata-rata, jika data memenuhi kriteria normalitas dan homogenitas maka pengujian menggunakan uji t yaitu independent Sample T-test, sedangkan untuk data yang normal tetapi tidak homogen maka pengujiannya menggunakan uji t' yaitu independent sample t-test.

\section{HASIL PENELITIAN DAN PEMBAHASAN}

\section{Hasil Penelitian}

Berdasarkan hasil tespenalaran matematik diperoleh data yang disajikan pada Tabel 1.

Tabel 1.

Deskripsi data kelas eksperimen dan kontrol

\begin{tabular}{|c|c|c|c|c|c|c|}
\hline \multirow{2}{*}{$\begin{array}{c}\text { Data } \\
\text { Statistik }\end{array}$} & \multicolumn{2}{|c|}{ Kelas Eksperimen } & \multicolumn{3}{|c|}{ Kelas Kontrol } \\
\cline { 2 - 7 } & Pretes & Postes & Gain & Pretes & $\begin{array}{c}\text { Poste } \\
\text { s }\end{array}$ & Gain \\
\hline $\mathrm{N}$ & 35 & 35 & 35 & 33 & 33 & 33 \\
\hline$\overline{\mathrm{x}}$ & 21,6 & 55 & 0,45 & 24,7 & 32,7 & 0.11 \\
\hline $\mathrm{S}$ & 13,3 & 23,6 & 0,28 & 14,3 & 19,4 & 0,21 \\
\hline
\end{tabular}

Keterangan: Skor Maksimal Ideal (SMI) $=100$

Berdasarkan Tabel 1 dapat terlihat bahwa rata-rata nilai postes dan gain ternormalisai kelas eksperimen lebih besar daripada ratarata kelas kontrol. Secara umum terlihat bahwa terdapat perbedaan 
pencapaian dan peningkatan penalaran matematik, yaitu pencapaian dan peningkatan penalaran matematik siswa yang pembelajarannya menggunakan pendekatanopen-ended lebih baik daripada yang menggunakan pembelajaran konvensional.Asumsi tersebut perlu dibuktikan kebenarannya menggunakan perhitungan statistik dengan bantuan program software MINITAB 16.

Setelah dilakukan uji normalitas dan uji homogenitas terhadap hasil data postes pada kelas eksperimen dan kelas kontrol, dan hasilnya diperoleh normal dan homogen, maka langkah terakhir dalam menganalisa hasil data postes ini adalah menguji hipotesis data. Dalam melakukan uji hipotesis ini dilakukan dengan uji perbedaan dua rata-rata atau uji-t. Hipotesis yang diajukan adalah:

$\mathrm{H}_{0}: \mu_{1} \leq \mu_{2}$ (Pencapaian penalaran matematik siswa antara yang pembelajarannya menggunakan pendekatan open-ended tidak lebih baik daripada yang menggukakan pembelajaran konvensional)

$\mathrm{H}_{\mathrm{a}}: \mu_{1}>\mu_{2}$ (Pencapaian penalaran matematik siswa antara yang pembelajarannya menggunakan pendekatan open-ended lebih baik daripada yang menggukakan pembelajaran konvensional).

Kriteria pengujian: $P$-Value $\geq 0,05$ maka $\mathrm{H}_{0}$ diterima.

Tabel 2.

Rekapitulasi pengujian perbedaan rata-rata data postes penalaran matematik

\begin{tabular}{|c|c|c|c|c|}
\hline Kelas & $\mathbf{N}$ & $\overline{\mathbf{x}}$ & $\mathbf{S}$ & P-Value \\
\hline Eksperimen & 35 & 55 & 23,58 & \multirow{2}{*}{0.000} \\
\hline Kontrol & 33 & 32,73 & 19,41 & \\
\hline
\end{tabular}

Hasil analisis uji hipotesis dengan bantuan software MINITAB 16 diperoleh nilai $P$-Value sebesar 0,000. Nilai tersebut kurang dari nilai signifikansi $\alpha=0,05 \quad(P<0,05)$ sehingga $\mathrm{H}_{0}$ ditolak, hal ini berarti bahwa pencapaian penalaran matematik antara siswa yang pembelajarannya menggunakan pendekatan open-ended lebih baik daripada yang menggunakan pembelajaran konvensional.

Setelah itu dilakukan uji normalitas dan uji homogenitas terhadap hasil data gainternormalisai pada kelas eksperimen dan kelas kontrol, dan hasilnya diperoleh normal dan homogen, maka langkah terakhir dalam menganalisa hasil data gain ini adalah menguji hipotesis data gainternormalisai. Dalam melakukan uji hipotesis ini dilakukan dengan uji perbedaan dua rata-rata atau uji-t. Hipotesis yang diajukan adalah:

$\mathrm{H}_{0}: \mu_{1} \leq \mu_{2}$ (Peningkatan penalaran matematik siswa antara yang pembelajarannya menggunakan pendekatan open-ended tidak lebih baik daripada yang menggukakan pembelajaran konvensional)

$\mathrm{H}_{\mathrm{a}}: \mu_{1}>\mu_{2}$ (Peningkatan penalaran matematik siswa antara yang 
pembelajarannya menggunakan pendekatan open-ended lebih baik daripada yang menggukakan pembelajaran konvensional).
Kriteria pengujian: $P$-Value $\geq 0,05$ maka $\mathrm{H}_{0}$ diterima.

Tabel 3.

Rekapitulasi pengujian perbedaan rata-rata data gain ternormalisasi penalaran matematik

\begin{tabular}{|c|c|c|c|c|}
\hline Kelas & $\mathbf{N}$ & $\overline{\mathbf{x}}$ & $\mathbf{S}$ & P-Value \\
\cline { 1 - 4 } Eksperimen & 35 & 0,447 & 0,281 & \multirow{2}{*}{0.000} \\
\cline { 1 - 3 } Kontrol & 33 & 0,112 & 0,203 & \\
\hline
\end{tabular}

Hasil analisis uji hipotesis atau uji perbedaan dua rata-rata dengan bantuan software MINITAB 16 diperoleh nilai $P$-Value sebesar 0,000 . Nilai tersebut kurang dari nilai signifikansi $\alpha=0,05 \quad(P<0,05)$ sehingga $\mathrm{H}_{0}$ ditolak, hal ini berarti bahwa peningkatan penalaran matematik antara siswa yang pembelajarannya menggunakan pendekatan open-ended lebih baik daripada yang menggunakan pembelajaran konvensional.

\section{Pembahasan}

Berdasarkan hasil analisis terhadap data pretes ternyata tidak terdapat perbedaan antara penalaran matematik siswa yang akan memperoleh pembelajaran menggunakan pendekatan open-ended dengan yang akan memperoleh pembelajaran konvensional. Dalam artian, kemampuan awal dari kedua kelas ini dapat dianggap sama hal tersebut dapat dimungkinkan siswa dulunya berasal dari populasi yang berkemampuan sama. Setelah postes kelas eksperimen yang mendapat pembelajaran open-ended, menunjukan hasil yang lebih baik dibandingkan dengan kelas kontrol yang pembelajarannya secara konvensional.

Sedangkan hipotesis yang diajukan dalam penelitian ini terbukti diterima.Artinya, "Pencapaian dan peningkatan penalaran matematik siswa yang pembelajarannya menggunakan pendekatan open-ended lebih baik dari pada siswa yang menggunakan pembelajaran konvensional".

Sedangkan hasil pengamatan penulis dilpangan hal ini disebabkan siswa yang pembelajarannya menggunakan pendekatan open-ended siswa lebih aktif dalam beraktifitas dan memiliki semangat yang tinggi dalam memecahkan setiap permasalahan yang ada pada pembelajaran openended.Kualitas aktifitas seperti ini cenderung meningkat dari pertemuan ke pertemuan berikutnya. Seperti kegiatan pembelajaran saat siswa mengerjakan permasalahan openended dengan bantuan jaring-jaring kubus yang mereka buat sendiri seperti pada gambar berikut. 


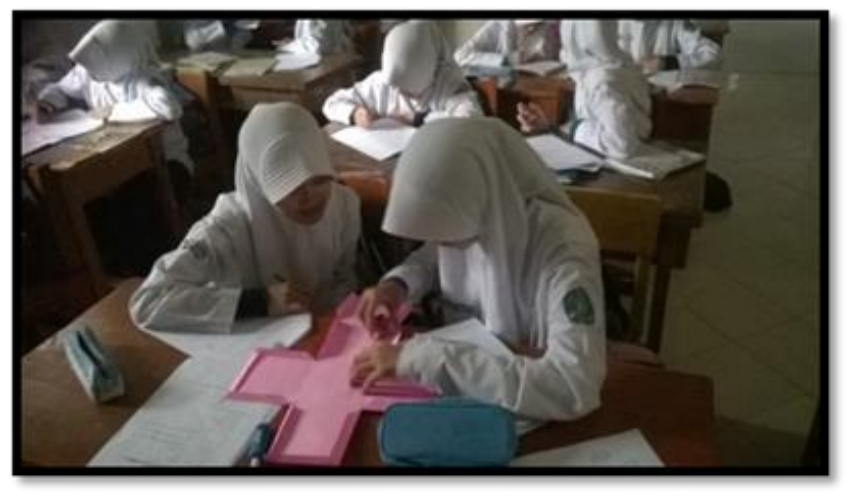

Gambar 1.

Siswa memecahkan permasalahan pada soal open-ended

Temuan peneliti saat di lapangan kegiatan pembelajaran dengan menggunakan pendekatan open ended sangat berbeda dengan yang menggunakan pembelajaran biasa. Pada pertemuan pertama siswa sangat belum terbiasa dengan menggunakan pembelajaran open ended, dimana siswa masih terasa sangat asing dengan soal-soal LKS yang di berikan dan juga ketika siswa dihadapkan dengan soal pemecahan masalah secara lisan siswa kurang percaya diri untuk menjawab. Kemudian pada saat mengerjakan LKS yang berisi pertanyaanpertanyaan open ended siswa ragu atas jawaban yang ia kerjakan berbeda dengan jawaban yang temannya kerjakan dan pada saat pembelajaran siswa kurang aktif, mereka cenderung masih malu-malu dan juga belum terbiasa persentasi di depan kelas, sehingga mereka cenderung mengandalkan temannya untuk mempresentasikan hasil kerjanya di depan kelas.

Setelah diberi motivasi dan sedikit interpensi pada awal pertemuan oleh guru maka pada pertemuan kedua, ketiga, dan berikutnya siswa sudah mengalami perkembangan dalam pembelajaran. Siswa sudah memiliki kepercayaan diri dalam mengerjakan LKS dan menjawab pertanyaan-pertanyaan lisan, siswa sudah tidak malu-malu untuk persentasi di depan kelas, dan siswa menjadi aktif karena tidak mengandalkan temannya lagi. Hal ini sejalan dengan penelitian Faridah dkk (2016) yang mengatakan bahwa "proses pembelajaran siswa dengan open ended yang menuntut siswa untuk memiliki kepercayaan diri akan menghasilkan siswa yang optimis dalam melakukan suatu tindakan, mudah berinteraksi dengan orang lain, memiliki tujuan yang ingin dicapai dan selalu berupaya yang terbaik untuk dapat mencapai tujuan tersebut.".

\section{KESIMPULAN DAN SARAN}

\section{Kesimpulan}

Berdasarkan hasil penelitian dan anlisis data yang telah dikemukakan, dapat disimpulkan bahwa pencapaian dan peningkatan penalaran matematik antara siswa yang pembelajarannya menggunakan pendekatanopen-ended lebih baik 
daripada yang menggunakan pembelajaran konvensional.

Saran

Untuk implementasi pembelajaran open-ended dalam proses pembelajaran maka perlu mempertimbangkan waktu yang tersedia, pengelolaan kelas dengan seting berbeda serta meningkatkan kesiapan siswa untuk penguatan materi prasyarat sebelum konsep yang baru akan disajikan.

\section{DAFTAR PUSTAKA}

Faridah, N., Isrok'atun., Nuraeni, A. (2016). Pendekatan Open Ended untuk

Meningkatkan

Kemampuan Berpikir Kreatif Matematis dan Kepercayaan Diri Siswa. Jurnal Pena Ilmiah. Vol. 1, Nomor.1:1064.

Haryono, A. D. (2008). Belajar Bermakna. [Online]. Tersedia: http://aflah.wordpress.com/2008 /02/23/BelajarBermakna/ $\quad[01$ April 2014].

Juariah.(2008). Meningkatkan kemampuan Penalaran dan Komunikasi Matematis Siswa melalui Pendekatan Keterampilan Proses Matematika.Tesis pada SPs UPI. Bandung: Tidak Diterbitkan.

Kasmiri, A. R. (2005).Penerapan Pendekatan Matematika Realistik pada Pembelajaran Lingkaran untuk Meningkatkan Kemampuan Penalaran Siswa. Skripsi FPMIPA UNLA. Bandung: Tidak Diterbitkan.
Mahmudi, A. (2008). Mengembangkan Soal Terbuka (Open-Ended Problem) dalam Pembelajaran

Matematika.[Online].Tersedia : http://zonasabar.blogspot.com/2 011/03/makalah-pembuatan-lkslembar-kerja.html.[18 januari 2012].

Ruseffendi, E.T. (2005). Dasar Dasar Penelitian Pendidikan dan Non-Eksakta Lainnya. Bandung: Tarsito.

Shadiq,F. (2007). Penalaran atau Reasoning.

[Online].Tersedia:http://prabu.te lkom.us/2007/08/29/_[08April 2014].

Suherman, E, et.al. (2001). Strategi Pembelajaran Matematika Kontemporer.Bandung: JICAUPI.

Sumarmo, U. (2002). Alternatif Pembelajaran Matematika dalam Menerapkan Kurikulum Berbasis Kompetensi.Makalah pada Seminar Tingkat Nasional FPMIPA UPI. Bandung: Tidak Diterbitkan.

Urman.(2010). Pembelajaran Berbasis Masalah Terstruktur untuk Meningkatkan Kemampuan Penalaran Matematik Siswa SMP.Tesis pada SPs UPI. Bandung: Tidak Diterbitkan.

Yuniarti, Y. (2007). Meningkatkan Kemampuan Penalaran dan Komunikasi Matematis Siswa Sekolah Menengah Pertama melalui Pembelajaran dengan Pendekatan Inkuiri.Tesis pada SPs UPI. Bandung: Tidak Diterbitkan 